\title{
The history of the Geophysical Service of Austria
}

\author{
Wolfgang A. Lenhardt \\ Department of Geophysics, Zentralanstalt für Meteorologie und Geodynamik (ZAMG), Vienna, Austria \\ Correspondence: Wolfgang A. Lenhardt (wolfgang.lenhardt@zamg.ac.at)
}

Received: 25 August 2020 - Revised: 19 November 2020 - Accepted: 25 November 2020 - Published: 15 January 2021

\begin{abstract}
A brief summary will be given of the historical development of Geophysical Service of Austria, which comprises the national geomagnetic, gravimetric and seismological services as well as the "Applied Geophysics Section" located at the Zentralanstalt für Meteorologie und Geodynamik (ZAMG) in Vienna in Austria. The paper presents the achievements, changes and challenges of the Department from its modest beginning in 1851 until 2020. Finally, a special emphasis is placed on the Conrad Observatory - one of the most comprehensive geophysical research observatories in the world.
\end{abstract}

\section{Introduction}

In 2021, the Zentralanstalt für Meteorologie und Geodynamik (Central Institute for Meteorology and Geodynamics, ZAMG for short) celebrates its 170th anniversary. This recurrence justifies a brief overview of its history (Toperczer, 1975; Hammerl, 2001; Hammerl et al., 2001) and achievements. The ZAMG's development reflects the evolution of technology and the changing expectations of a national public service, especially with the advent of computers. Today, the ZAMG provides a large number of services beyond its core weather forecasting and geophysical monitoring activities, which include comprehensive climate observations, phenology, modelling of the Earth magnetic field and its interactions with the Sun and the atmosphere, geophysical surveys, and monitoring of earthquakes. These activities, along with the ZAMG archives hosting the longest history of meteorological and geophysical observations in Austria, provide key support for risk assessment and decision-making at a national and international level. Today, the ZAMG belongs to the Federal Ministry for Education, Science and Research (BMBWF) and currently has 324 employees including 187 scientists working in the headquarters and four external offices as well as at two observatories - the "Sonnblick" (meteorology) and the "Conrad" (geophysics). The Geophysical Service of Austria - being part of the ZAMG - consists of 31 persons.

Despite national services (Austrian Commission on Large Dams, the Austrian Standards Institute for earthquake resis- tant building engineering), the Austrian Geophysical Service maintains permanent contact with international organizations such as the International Association for Geomagnetism of Aeronomy (IAGA), INTERMAGNET, the International Association of Seismology and Physics of the Earth's Interior (IASPEI), the Observatories and Research Facilities for European Seismology (ORFEUS), the European-Mediterranean Seismological Centre (EMSC), and the Federation of Digital Seismograph Networks (FDSN). In addition, the department hosts the National Data Centre of Austria (NDC-AT) as national point of contact of the Comprehensive Nuclear-TestBan Treaty Organization (CTBTO). In 2014, Italy (OGS), Slovenia (ARSO) and the ZAMG-Geophysics founded the Central and Eastern Europe Earthquake Research Network "CE ${ }^{3} \mathrm{RN}^{\prime}$ (e.g. Picozzi et al., 2014; Pesaresi et al., 2017). This initiative not only allowed several institutions to organize common projects, but also solidified co-operations across borders and supports civil protection.

\section{Historical development}

On 13 May 1848 - in the midst of the revolution in the Austrian Empire - Andreas Baron of Baumgarten of the Austrian Academy of Sciences, which was founded just a year before in 1847 , suggested to equip the newly built railway stations with meteorological instruments to monitor the weather across the Austro-Hungarian Empire.

On 24 June 1848 Karl Kreil - then director of the Astronomical Observatory in Prague - furnished a concept of a 


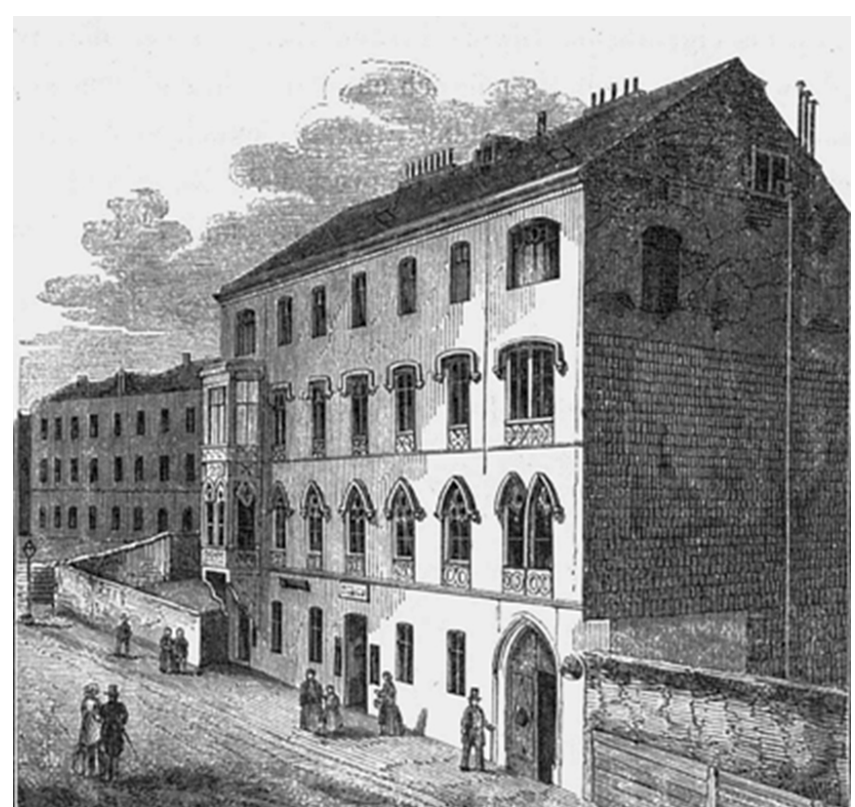

Figure 1. First quarters of the institution 1852 (ZAMG, 1856).

future meteorological network which included not only railway stations but also astronomical observatories and clerical and scientific institutions. Kreil listed 22 tasks which covered phenological, biological, magnetic, electric, earthquake, astronomical observations and air chemistry in his concept. After another year of consultations and preparing a profound proposal on the advice of his Minister for Science and Education Count Leopold of Thun and Hohenstein, the "Zentralanstalt für Meteorologie und Erdmagnetismus" (Central Institute for Meteorology and Geomagnetism), as it was named then, was founded by Emperor Franz Joseph I on 23 July 1851.

\subsection{Geomagnetic surveys: 1851-1904}

Karl Kreil (1778-1862) served as the first director of the institute, which was established at the Academy of Sciences in the centre of Vienna. Kreil had already been acquainted with magnetic measurements since 1842 and his survey campaigns between 1842 and 1857 culminated in the first geomagnetic map of the Austrian Empire, southern Europe, the Adriatic Sea, Turkey and the Black Sea for the Epoche 1850.0. Geomagnetic maps were of immense scientific and military value. Owing to the varying nature of the geomagnetic field due to secular variations, the surveys were now repeated every few decades to maintain state-of-the-art information on the Earth's magnetic field.

In 1852 new offices in Favoritenstraße 303 (in today's 4th district of Vienna) housed staff members and instruments for weather and geomagnetic monitoring (Fig. 1). Seismometers were not available at that time, which prompted Kreil to publish a paper on a seismograph (Kreil, 1855), which consisted

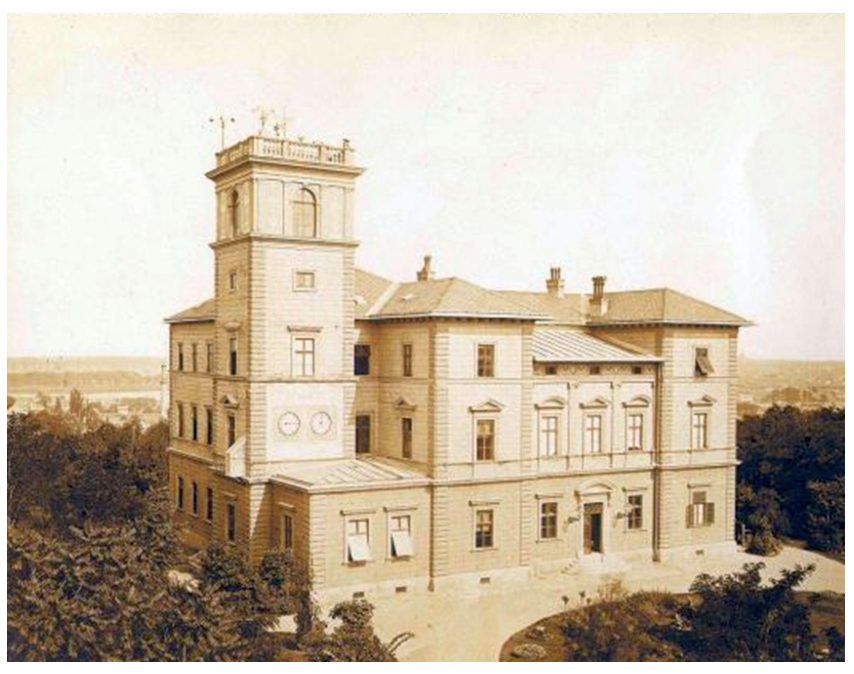

Figure 2. Home of ZAMG since 1872 at the Hohe Warte in Vienna (ZAMG archive).

of a permanent recording system in combination with a device - similar to Zhang Heng's famous seismoscope from 132 AD in China (e.g. Dewey and Byerly, 1969) - indicating the direction and "strength" of an incoming earthquake ground motion. Kreil seems to have designed this instrument between 1848 and 1850, with parts apparently still preserved at the National Technical Museum in Prague (Oldroyd et al., 2007). Whether this instrument was ever completed or not remains very uncertain, as no seismograms survived or were referred to. Kreil then summarized the magnetic observations he made during this first geomagnetic survey, which was published posthumously (Kreil, 1862). The second large geomagnetic survey took place in 1890 .

In 1872 the institute moved to a new building, which was specially built for that purpose by the Viennese architect Heinrich Ferstel at the Hohe Warte (today's 19th district in Vienna, Fig. 2) where the institute still maintains it Headquarters.

In the late hours of Easter Sunday in 1895 a strong earthquake hit Ljubljana (at that time part of the Imperial and Royal Austrian Empire, now Slovenia; Fig. 3), which initiated intensive investigations as to whether and where the Austrian Empire was already vulnerable to similar or even worse earthquakes with more dramatic consequences.

It was this earthquake which led to the establishment of the Slovenian Seismological Service (known in those days as "Erdbebenwarte in Laibach"). Personnel limitations by the Academy of Sciences led to the addition of seismological observations to the agenda of the purposely renamed Zentralanstalt für Meteorologie und Geodynamik with effect of 2 March 1904. Observations of earthquake effects had already been reported by 14 earthquake "correspondents" since 1895, who gathered the reports from hundreds of observers. The correspondents regularly published the results in jour- 


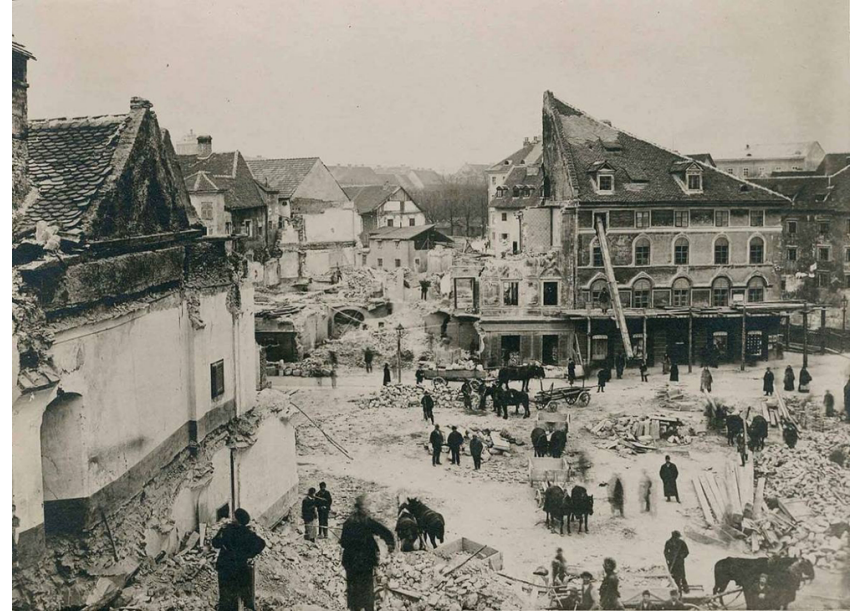

Figure 3. Earthquake damage in Ljubljana 1895 (TSN, 2020).

nals of the Imperial and Royal Austrian Academy of Sciences (Hammerl, 2001). At this time earthquake-related observations were added to the routine meteorological and geomagnetic agenda of the ZAMG.

\subsection{The advent of seismology: 1904-1939}

The newly established Seismological Service of Austria ("Österreichischer Erdbebendienst") benefitted from earlier studies by prominent scientists like Eduard Suess (1873; see also Brückl and Hammerl, 2014) who already described the seismicity of Lower Austria (the province surrounding the capital Vienna). By that time, Rudolf Hoernes (1878) had already categorized seismic events into "earthquakes", "volcanic tremors" and "collapse events", the latter being frequently observed in the Karst region in Slovenia.

The most famous seismologist of the ZAMG was certainly Victor Conrad (1876-1962, Fig. 4), who also analysed meteorological time series and worked as a climatologist. He headed the Seismological Service from 1904 to 1910, when he left to take assume a newly created chair on "Cosmic Physics" at the Chernivtsi National University in Bukovina - today Ukraine. He returned in 1919 to lead the Department again until 1934 when Conrad was succeeded by Rudolf Schneider. The advent of the Nazi regime in 1938 prompted Victor Conrad, who was of Jewish descent, to leave Austria and to emigrate to the USA, where he lectured climatology again at several universities - eventually at Harvard University in Cambridge, Massachusetts - until 1951.

Given the mean financial situation of the ministry, Conrad was advised to develop a cost-effective seismic instrument (Conrad, 1910). The "Conrad pendulum" was much smaller (with a suspended mass of $25 \mathrm{~kg}$ ) than the Wiechert seismograph (Wiechert, 1904) and easy to transport and to install. It proved to be very sturdy - and recorded many stronger ground motions, when the Wiechert seismograph "clipped".

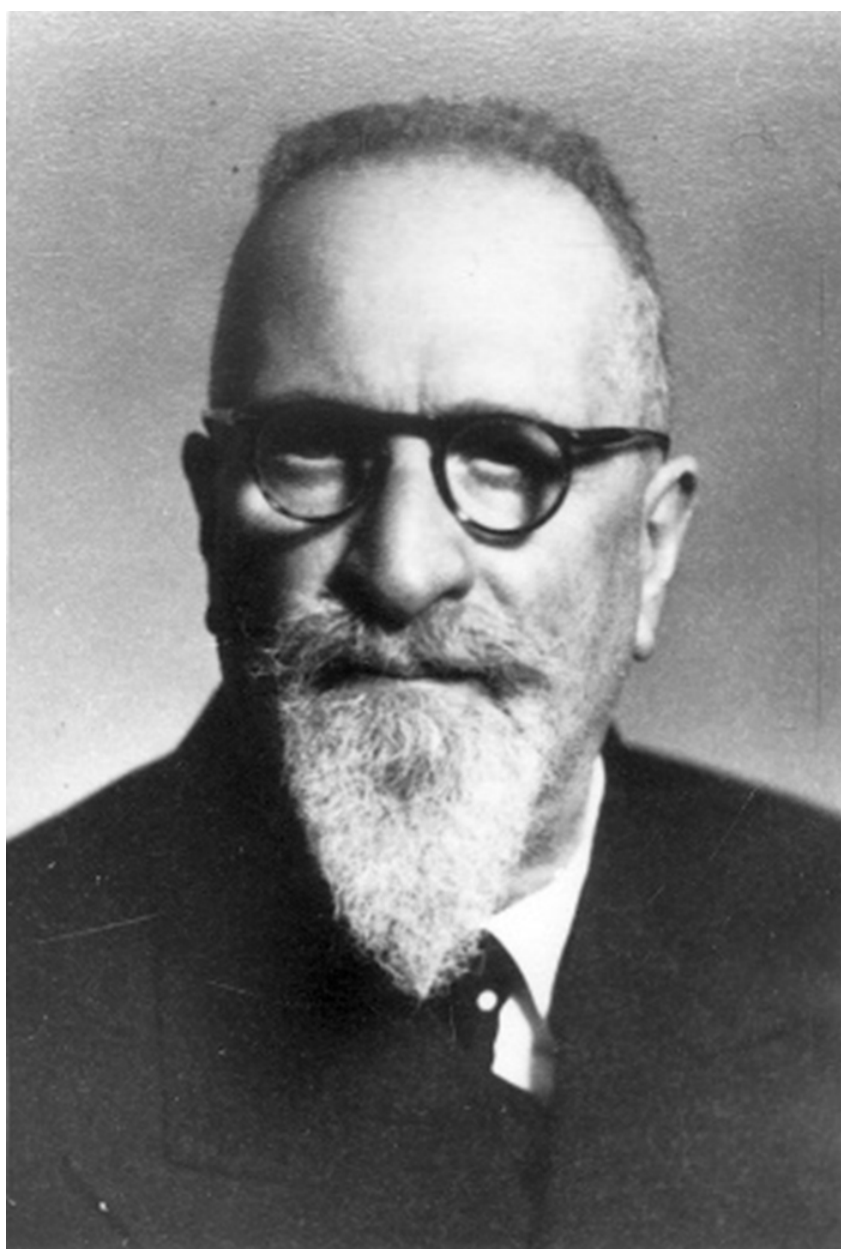

Figure 4. Victor Conrad (1876-1962) (ZAMG archive).

As the pendulum was much less sensitive (by a factor of at least 10), it was hardly of any use for recording distant earthquakes. Despite these shortcomings, these instruments were then distributed across the monarchy, enabling seismologists to analyse all kinds of seismological aspects such as temporal earthquake distributions for example (Conrad, 1932) as they proved to be very valuable regionally. Conrad became most famous for his exchange of observations and ideas with Harold Jeffreys (see also Conrad, 1925; Jeffreys, 1927) suggesting a discontinuity, separating the upper from the lower Earth's crust, which later became known as the Conrad discontinuity.

Meanwhile, the seismic observatory in the basement of the ZAMG main building at the Hohe Warte hosted several seismometers: three Vicentini pendulums (two horizontal and one vertical; see Vicentini and Pacher, 1896, 1898) and an Wiechert inverted pendulum $(1000 \mathrm{~kg})$ for recording the two horizontal components, as well as a Wiechert seismograph for vertical recordings (mass $1300 \mathrm{~kg}$ ) (Conrad, 1909).

As the Austro-Hungarian monarchy dissolved in 1918, the Republic of Austria was formally established in 1919, and 
most parts of the previous empire became independent in 1919, thus falling under the influence of Russia, whereas South Tyrol belonged now to Italy. Owing to the new political situation, the third geomagnetic survey in 1930 was carried out in Austria on a much smaller scale. For that purpose a geomagnetic base observatory was erected at Auhof on the outskirts of Vienna, which was in operation from 1928 to 1945 .

\subsection{World War II: 1939-1945}

Just a little more than two weeks after the Second World War had begun, the Puchberg earthquake occurred south of Vienna on 18 September 1939. News about this earthquake, which claimed two lives, were largely obscured by the much larger human loss of the Battle of the Bzura (west of Warsaw in Poland), which marked the German advance in Poland. From now on, the collection of macroseismic reports became severely hampered - and even more impeded by the massive reductions in personnel when all young staff members were drafted by the military.

Air raids on 9 November 1944 (Allied Forces) and German artillery attacks on 20 February 1945 almost destroyed the ZAMG at the Hohe Warte, causing extensive damage to the seismographs in the basement (Fig. 5).

In April 1945, just before the end of the war, the magnetic observatory at Auhof in the south-east of Vienna was completely destroyed.

\subsection{The postwar years: 1945-1955}

The transitional years between World War II and Austria's independence were characterized by the recovery of destroyed instruments and archives. The pendulums of Vicentini were irreparably lost, and the vertical Wiechert seismograph and the Conrad pendulum were repaired and put into service again on 15 September 1948. The repair of the "horizontal Wiechert" took much longer - until 23 June 1950 (Toperczer, 1975). Based on documentation and recordings from 1904 to 1948 the first earthquake catalogue was published (Toperczer and Trapp, 1950). At this time, the list of earthquakes was not scrutinized in any way but accepted as it was.

The repairs of the geomagnetic observatory at Auhof took much longer than expected, and magnetic observations resumed on 18 September 1951 for less than a year until its definitive dismissal on 14 July 1952, due to the magnetic disturbances associated with the increasing city electrification (Toperczer, 1975). A new site for these geomagnetic observations was needed to warrant conclusive measurements.

\subsection{Entering modern times: 1955-1990}

As the ZAMG headquarters at the Hohe Warte were also affected by the city's progressing electrification, a new location for the magnetic observatory was found at a former

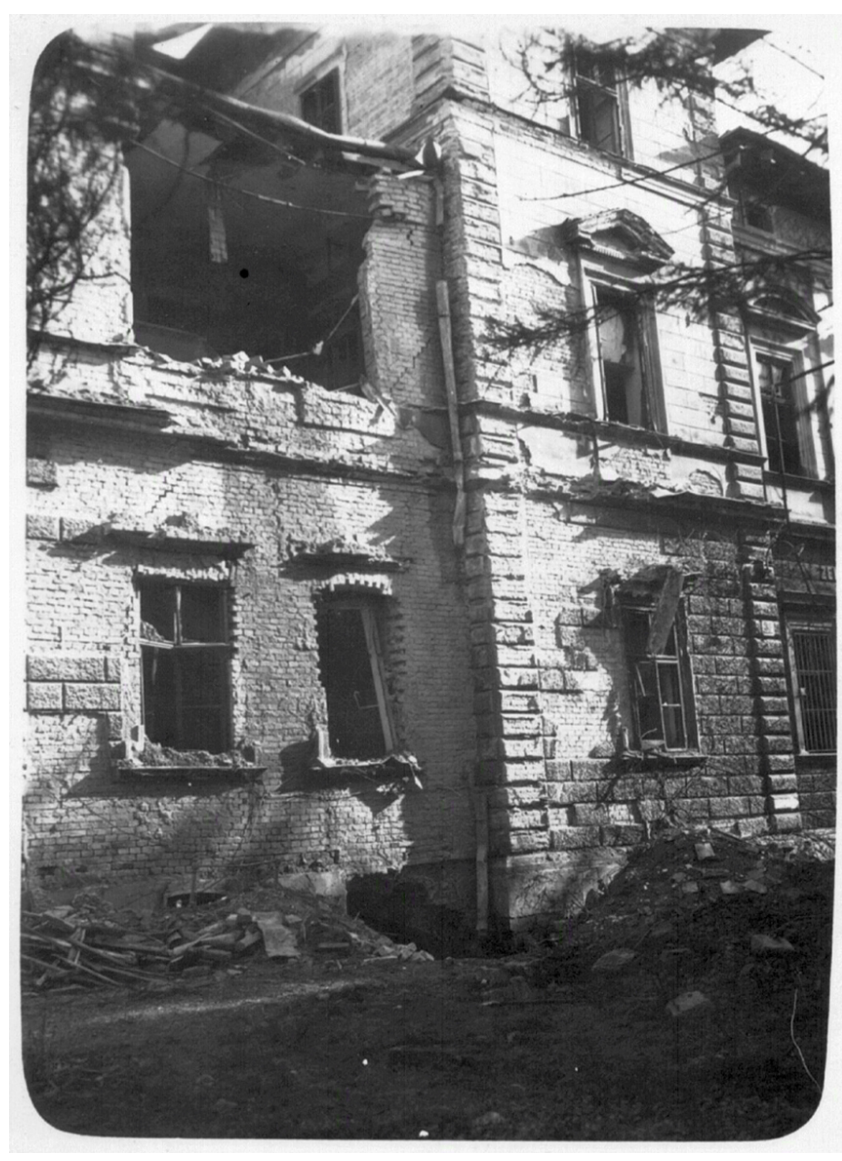

Figure 5. Damaged main building in 1944 (ZAMG archive).

riding camp of the US Army at the Cobenzl in the Vienna Woods (Fig. 6), not far from the ZAMG Headquarters. The new Cobenzl geomagnetic observatory (mostly spelled "Kobenzl" in publications; see Toperczer, 1956) continuously operated from 1954 to 2016. It was eventually equipped with seismometers and officially inaugurated during the General Assembly of the European Seismological Commission (ESC) in Vienna in 1956. Therefore, the Cobenzl observatory can be regarded as the first true "geophysical observatory" in Austria (with the exemption of gravimetric observations).

Successive geomagnetic surveys took place in 1960 and 1970 and served as references for the first aeromagnetic survey by the Geological Survey of Austria in 1977 (Gutdeutsch and Seiberl, 1987). Already at that time, increasing magnetic disturbances from the expanding electrified city transportation system became evident again. The continued worsening of the magnetic record quality initiated the first plans to relocate the magnetic observatory far from Vienna, but close enough to enable continuous maintenance.

Given the vast amount of data stemming either from macroseismic reports, local seismograms or international seismological centres, the Seismological Service of Austria 


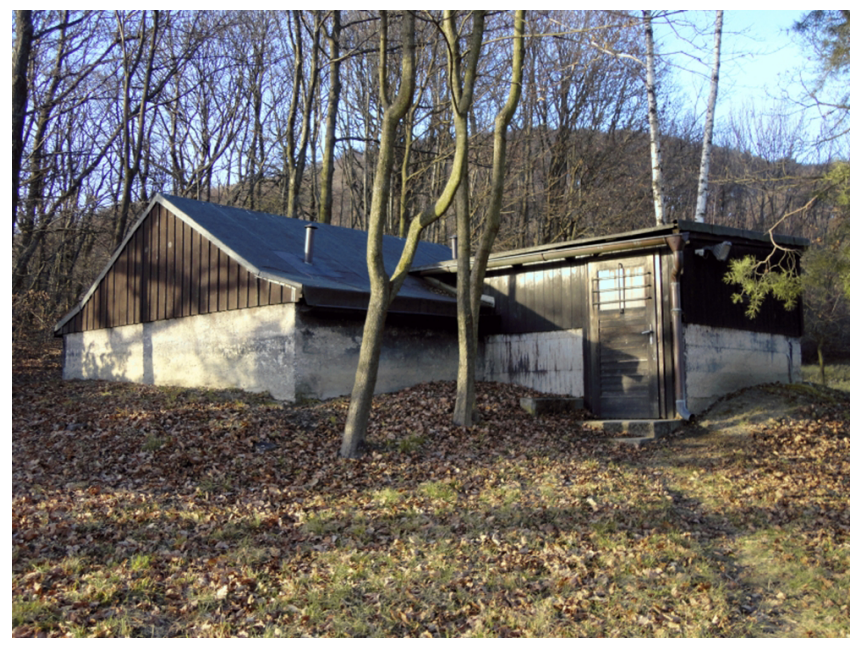

Figure 6. Main part of the former geomagnetic observatory at the Cobenzl in Vienna, which was in operation from 1954-2016 (ZAMG archive).

was able to publish summaries of the earthquake activity in Austria (Drimmel et al., 1970; Drimmel and Trapp, 1982) while making use of these data to estimate possible maximum intensities for the territory (Drimmel, 1979). The latter was important for assessing the seismic hazard of planned industrial projects such as large dams, nuclear power plants and infrastructure in general. The series of earthquakes in Friuli (Italy) in 1976 drew attention to the proper earthquakeresistant design of private dwellings, as many of them suffered damage in Southern Carinthia. As a consequence, the Austrian building code for earthquake-resistant design was updated and a new version was published in 1979 (ÖNORM, 1979).

As the lack of knowledge of the local earthquake activity in Austria became a matter of dispute between geoscientists during the final planning phase of the nuclear power plant in Zwentendorf near Vienna, historical earthquake research (Gutdeutsch et al., 1987) was initiated. Shortly thereafter, several seismic stations were installed across Austria by the University of Vienna, which supported the study of the Earth's crust in the Eastern Alps (Aric et al., 1989). This cooperation with the University of Vienna had a long standing, as professors from the university were routinely entrusted with the directorship of the ZAMG, and ZAMG scientists lectured at the university.

After more than 70 years of service both Wiechert seismographs were taken out of operation on 10 March 1977. The Conrad pendulum was in use until 4 May 1981, and a vertical short-period seismometer (Sprengnether S-5007; see also Moore et al., 2018) was used from 1 January 1973 to 31 December 2006 in the basement of a new building at the Hohe Warte.

At this point, more emphasis was given to seismic instruments and records from the Cobenzl, which were record- ing in parallel, as the seismic background at the Hohe Warte at the time exceeded acceptable limits. Two horizontal short-period seismometers (also of the Sprengnether type) were in operation from 1 January 1973 to 16 September 1981 and replaced with "very broadband feedback" seismometers (Streckeisen STS-1; Holcomb and Hutt, 1992) on 25 March 1983, which were used until 19 August 2002. The longest period of continuous seismic records was made at the Cobenzl with a short-period seismometer from 20 January 1982 to 31 December 2006.

\subsection{The digital age: $1990-2020$}

The first digital seismic station went into operation on 31 May 1989 at the Walderalm in Tyrol. This station marked the beginning of a local network which was then expanded to four stations in 1991. Since then, the seismic network has seen numerous additions of digital stations (see also Lenhardt et al., 2001). The first sensors in use were short-period seismometers which were later replaced with broadband sensors. Strong-motion stations supplemented the network in built-up areas for comparing recorded ground motions with earthquake-related building damage. Since 2002 all instruments now undergo rigid tests at the Conrad Observatory near Vienna.

In 1995 a proposal for an update of the seismic hazard map of Austria was put forward (Lenhardt, 1995) and implemented by the Austrian Institute of Codes (ÖNORM, 1997). At this time, it became custom to review earthquake catalogues by historians. Hence, historical earthquake research was added to the department's agenda leading to important improvements in the earthquake catalogue of Austria. This was the first time historical earthquake information from Austria was scrutinized and interpreted professionally. The increasing amount of data gave rise to a number of publications concerning the general seismicity of Austria (Hammerl and Lenhardt, 1997) and historical earthquakes (e.g. Hammerl and Lenhardt, 2013). During these investigations some earthquakes were found to be "fake quakes" and numerous earthquakes were discovered in so-far unknown sources. The reason for these fake quakes in the earthquake catalogue was unscrutinized copying of older catalogues which misprinted dates or years or misunderstood and associated other natural catastrophes such as floods from elsewhere with earthquakes in Austria (Hammerl and Lenhardt, 2013).

The information of regional historical seismic activity and the resulting seismic hazard map also allowed areas where stronger earthquakes tend to happen to be delineated. This proved to be useful when an earthquake in Bovec (Slovenia) in 1998 happened, which also affected Austrian territory. As a consequence, a 24/7 service for the Austrian warning centres was officially established on 1 April 2000. The same year also marked the transition from paper to online questionnaires published on the ZAMG website to gather near-real-time public responses from earthquakes. This ser- 
vice permits the ZAMG to disseminate relevant information to regional disaster protection centres to foster action. As of 2020 , the seismic network consists of 28 broadband stations (some of which are also equipped with strong-motion sensors, and more than 30 strong motion stations, of which 6 are installed in Vienna alone (Duma, 1996, when the network became installed).

Peter Melichar (Head of Department 1991-2009) founded the new division of "Applied Geophysics" in 1991 to take care of archaeological prospection by means of geophysical methods - an area of research and development at the already ZAMG since 1982. Meanwhile, the Applied Geophysics group is also dealing with dam investigations and mine safety and with the development of new tools for automatic pre-processing of field data (e.g. Aßmann et al., 2001; Neubauer et al., 2001, 2013; Seren et al., 2001a, b). The division of "Applied Geophysics" also collaborates closely with the Ludwig Boltzmann Institute for Archaeological Prospection and Virtual Archaeology in Austria since its foundation in 2010, and many astounding findings can be attributed to this initiative (e.g. Seren et al., 2011; Neubauer et al., 2012; Sakal et al., 2014; Sevara et al., 2020), not to mention the recent survey of the Durrington Walls near Stonehenge, which provided new insights into the celtic culture in England (ZAMG, 2020) and the cultural extent of Stonehenge.

In 1996, a superconducting gravimeter by GWR Instruments ${ }^{\circledR}$ (Meurers et al., 2001) was installed in the basement of the Kreil building at the ZAMG headquarters in Vienna. It was at this time that Peter Melichar coined the name "Geophysical Service of Austria" as the department constituted the only governmental institution in Austria to cover all geophysical disciplines on a national level: seismology, geomagnetics, gravimetry and applied geophysics.

In addition, geomagnetic research at the ZAMG has expanded considerably during the last years, aided by the seventh geomagnetic survey between 1995 and 1998 (Berger at al., 2001), and now includes many interdisciplinary subjects related to the reconstruction of past geomagnetic variations, the interaction of the Earth magnetic field with living organisms and with the atmosphere, and the occurrence of magnetic minerals in rocks and sediments as markers for tectonic and environmental processes. Such research is mainly carried out at the Conrad Observatory.

\section{The Conrad Observatory}

\subsection{Overview}

Based on a decree by Victor Conrad's wife Ida Conrad, and financial support from the Austrian Government, the geophysical observatory at the Trafelberg south-west of Vienna, just a $1.5 \mathrm{~h}$ drive from the ZAMG, could be constructed. The site was selected by Peter Melichar (then Head of Department), who also took care of the planning and design as well as the whole technical set-up. Due to the remoteness of the

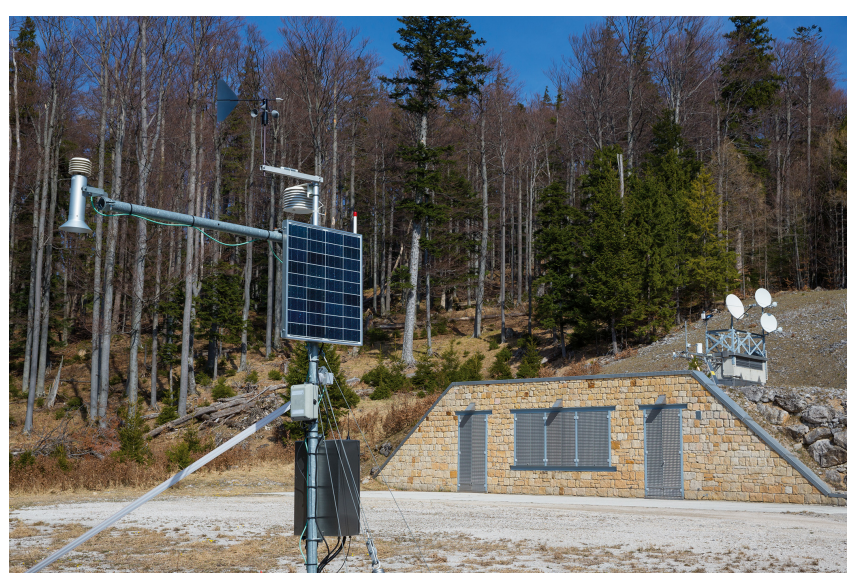

Figure 7. The Conrad Observatory - SGO (ZAMG, 2014).

selected site, the observatory had to be equipped with all necessary infrastructure from scratch, as there was no water supply, no electricity, and no telephone or internet. The observatory consists of two parts: the Seismological and Gravity Observatory (SGO) and the Geomagnetic Observatory (GMO).

\subsection{The Seismological-Gravitational Observatory (SGO)}

The SGO (Fig. 7, weather station in the foreground, satellite dishes in the background to connect to the International Data Centre of the CTBTO) was inaugurated on 23 May 2002. The building operations lasted from 13 July 1998 to 19 October 2000 to advance a $145 \mathrm{~m}$ long tunnel for seismic instrumentation into the Trafelberg mountain and to establish a laboratory for gravity measurements, a calibration table for seismometers and to sink four boreholes (one with a depth of $50 \mathrm{~m}$ for testing geophone chains and three boreholes down to $100 \mathrm{~m}$ for research purposes). Gravity measurements are carried out in co-operation with the Austrian Federal Office of Metrology and Surveying (BEV) for which the observatory also serves as a basic measuring point.

It took another 12 years to develop the Geomagnetic Observatory, which was the original reason for the remote site selection.

\subsection{The Geomagnetic Observatory (GMO)}

The GMO was officially inaugurated on 21 May 2014. It consists of an underground infrastructure with a total tunnel length of $1 \mathrm{~km}$, and a rock laboratory to analyse magnetic properties of rock samples equipped with most modern magnetometers and a thermal demagnetizer.

The main objective of the observatory, however, is monitoring the Earth's magnetic field under optimized conditions (e.g. temperature, noise). The geomagnetic variation measurement system also takes into account thermal conditions. The entire measuring system consists of various instruments. The sheer amount of different devices ensures the most ac- 


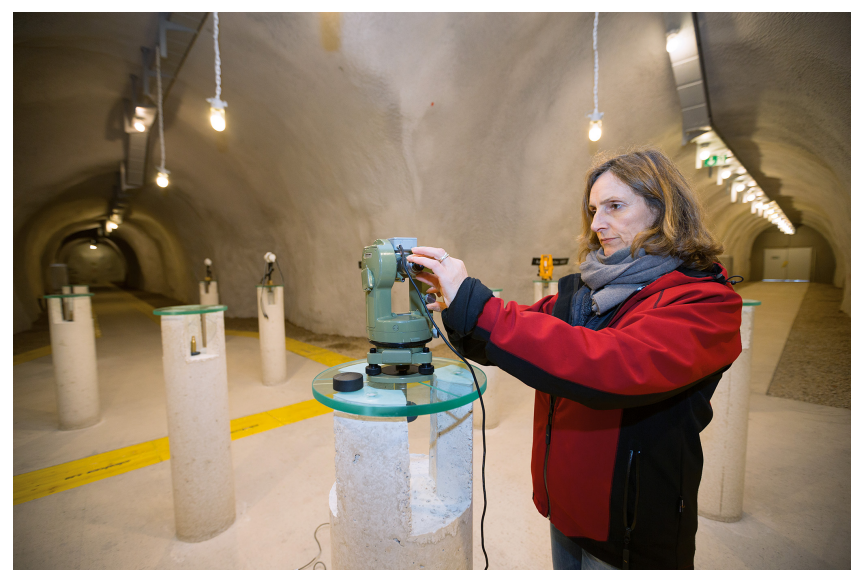

Figure 8. Manual control of automatic measurements of the geomagnetic field taken at the Conrad Observatory - GMO (ZAMG, 2014).

curate measurements in permitting the detection and elimination of undesired "noise", thus enabling the determination of time-varying gradients of the geomagnetic field in all directions with utmost precision. Readings are taken automatically and manually checked on a regular basis (Fig. 8).

Additional geomagnetic observing points are operating in an underground mine in Tyrol in the western part of Austria, which went into operation on 20 July 2017, and in Gams (Styria), which is maintained and operated by the University of Leoben. The measurements from Tyrol are transmitted in real time to the data centre at the ZAMG and are continuously compared with observations from the Conrad Observatory - thus covering the longitudinal range of Austria to a large extent in the $\mathrm{E}-\mathrm{W}$ direction, which coincides with the main movement of the secular variation of the geomagnetic field in that region.

\section{Looking ahead}

As all geophysical disciplines are being covered by the Geophysical Service Survey of Austria, specific research tasks have attracted special attention. Obviously, the more seismic stations are installed in Austria, the greater the ability to distinguish natural earthquakes from induced ones. The number of seismic stations of the national network are planned to be increased even further thus permitting the cause of a seismic tremor to be monitored more closely, whatever it might have been (exploitation, explosions, water reservoirs, rock falls - or natural earthquakes). Currently more than $50 \%$ of detected seismic events can already be attributed to man-made activities in Austria.

As the Conrad Observatory includes several tunnels of hundreds of metres in length, strain measurements appear to be very informative when compared with seismic observations in terms of seismic wave lengths and their resolution and accuracy. This principle applies also to gravimetric and magnetic measurements, which can be analysed there. In addition, space-weather forecasts became an issue when society began to rely on data transmission (internet) and magnetic storage systems. Such an early-warning system was introduced by the Geophysical Service in 2020 to assist the Austrian Power Grid.

Data availability. No data sets were used in this article.

Competing interests. The author declares that there is no conflict of interest.

Special issue statement. This article is part of the special issue "History of geophysical institutes and observatories". It is not associated with a conference.

Acknowledgements. The author would like to express his thanks to Barbara Leichter, Ramon Egli and Roman Leonhardt for providing technical details. Photographs used in the paper were obtained from the historical archive of the Department of Geophysics at the Zentralanstalt für Meteorologie und Geodynamik (ZAMG). Lois Lammerhuber took the photographs in Figs. 6 and 7 on behalf of the ZAMG. This article benefitted from comments and suggestions from two anonymous reviewers and the editor, whose assistance is gratefully acknowledged.

Review statement. This paper was edited by Kristian Schlegel and reviewed by two anonymous referees.

\section{References}

Aric, K., Gutdeutsch, R., Leichter, B., Lenhardt, W. A., Plomerova, J., Babuska, V., Padjusak, P., and Nixdorf, U.: Structure of the lithosphere in the Eastern Alps derived from P-residual analysis. Arbeiten aus der Zentralanstalt für Meteorologie und Geodynamik, Publ. Nr. 317, Vienna, Austria, 1989.

Aßmann, K., Dörrer, T., Lehmann, B., Lux, K., Seren, S., and Schön, J.: Geophysical investigations at different parts of the planned Koralm Tunnel, J. Eng. Geol., 6, 22-30, 2001.

Berger, J., Blaumoser, N., Duma, G., and Leichter, B.: The geomagnetic survey of Austria 1995-1998, Contributions to Geophysics and Geodesy, 31, 279-284, 2001.

Brückl, E. and Hammerl, C.: Eduard Suess' conception of the Alpine orogeny related to geophysical data and models, Austrian J. Earth Sc., 107, 94-114, 2014.

Conrad, V.: Beschreibung des seismischen Observatoriums der k.k., Zentralanstalt für Meteorologie und Geodynamik in Wien, Mitteilungen der Erdbeben-Kommission, Neue Folge Nr. 33, Österr. Akad. d. Wissenschaften, Vienna, Austria, 1909. 
Conrad, V.: Ein einfaches Instrument für seismische Stationen in habituellen Stossgebieten, Beiträge zur Geophysik, Bd. X, Heft 3, 157-160, 1910.

Conrad, V.: Laufzeitkurven des Tauernbebens vom 28. November 1923, Mitteilungen der Erdbeben-Kommission, Neue Folge Nr. 59, Österr. Akad. d. Wissenschaften, Vienna, Austria, 1925.

Conrad, V.: Die zeitliche Folge der Erdbeben und bebenauslösende Ursachen. Handbuch der Geophysik (edited by B. Gutenberg), Band IV, Gebrüder Bornträger, Berlin, 1007-1190, 1932.

Dewey, J. and Byerly, P.: The early history of Seismometry (to 1900), Bull. Seism. Soc. Am., 59, 189-227, 1969.

Drimmel, J.: On the assessment of maximum earthquakes in the Alps and adjacent areas, Tectonophysics, 55, 1-5, 1979.

Drimmel, J. and Trapp, E.: Die Erdbeben Österreichs 1971-1980, Sitzungsber. der Österr. Akad. d. Wiss., Mathem.-naturw. Kl. Ant. I, 191. Band, 1.-4. Heft, Vienna, 73-102, 1982.

Drimmel, J., Gangl, G., and Trapp E.: Kartenmäßige Darstellung der Seismizität Österreichs. Österr. Akad. Wiss., SpringerVerlag, Vienna, 1971, 23 pp., 1970.

Duma, G., Horn, N., and Vogelmann, A.: Seismisches StrongMotion Meßnetz in Wien. Projekt-Endbericht im Auftrag des Bundesministeriums für Wissenschaft and Forschung und der Stadt Wien, Zentralanstalt für Meteorologie und Geodynamik, 38 pp., Vienna, 1996.

Gutdeutsch, R. and Seiberl, W.: Die aeromagnetische Vermessung Österreichs - Endbericht, Inst. Meteor. Geoph. Univ. Wien, 8 Figs., 1 Table, 1 Map, Wien, 34 pp., 1987.

Gutdeutsch, R., Hammerl, C., Mayer, I., and Vocelka, K.: Erdbeben als historisches Ereignis, Die Rekonstruktion des Bebens von 1590 in Niederösterreich, Springer Verlag, Vienna, Austria, 221 pp., 1987.

Hammerl, C.: Die Geschichte der Zentralanstalt für Meteorologie und Geodynamik, in: Hammerl et al., 2001, 17-297, 2001.

Hammerl, C. and Lenhardt, W.: Erdbeben in Österreich, Leykam Verlag, Graz, 191 pp., 1997.

Hammerl, C. and Lenhardt, W.: Erdbeben in Niederösterreich von 1000 bis 2009 n. Chr. Abh. Geol. B.-A., Vienna, Vol. 67, 297 pp., 2013.

Hammerl, C., Lenhardt, W., Steinacker, R., and Steinhauser, P. (Eds.): Meteorologie und Geophysik in Österreich, A comprehensive compilation of the institutional history on the occasion of the 150-year jubilee of the Zentralanstalt für Meteorologie und Geodynamik, Wien, Leykam Verlag, 838 pp., 2001.

Hoernes, R.: Erdbebenstudien. Jahrbuch der k.k. geologischen Reichsanstalt, Vol. 28/3, 387-448, Vienna, 1878.

Holcomb, G. and Hutt, R.: Three Installations methods for the STS-1 were tested at the Albuquerque Seismological Lab (ALS), USGS Open File Report USA, 92-302, 1992.

Jeffreys, H.: On two british earthquakes, Monthly Notices of the Royal Astronomical Society, Geophysical Supplement, 1, 483494, 1927.

Kreil, K.: Über einen neuen Erdbebenmesser. Sitzungsberichte der math.-naturw, Classe der kais, Akademie der Wissenschaften, XV. Bd., p. 370, Vienna, 1855.

Kreil, K.: Magnetische und geographische Ortsbestimmungen im südöstlichen Europa und einigen Küstenpunkten Asiens, Sitzungsberichte der math.-naturw. Classe am 24. Juni 1859, Denkschriften, Bd. XX, 1862.
Lenhardt, W.: Regional earthquake hazard in Austria, Proc. of "10th European Conference on Earthquake Engineering", edited by: Duma, G., Balkema, 63-68, 1995.

Lenhardt, W., Melichar, P., Steiner, R., and Horn, N.: Erdbebenstationen in Österreich, in: Hammerl et al., 2001, 567-576, 2001.

Meurers, B., Blaumoser, N., Göschke, M., Haden S., Melichar, P., and Steiner R.: Das Supraleitende Gravimeter in Wien - ein Beitrag zur modernen geodynamischen Forschung, in: Hammerl et al., 2001, 608-618, 2001.

Moore, S. V., Hutt, C. R., Anthony, R. E., Ringler, A. T., Alejandro, A. C. B., and Wilson, D. C.: A Collection of Historic Seismic Instrumentation Photographs at the Albuquerque Seismological Laboratory, Seismol. Res. Lett., 90, 765-773, https://doi.org/10.1785/0220180267, 2018.

Neubauer, W.: Geophysikalisch-archäologische Prospektion an der ZAMG, in: Hammerl et al., 2001, 726-743, 2001.

Neubauer, W. and Seren, S.: Die Entdeckung der Gladiatorenschule in Carnuntum, Acta Carnuntina, 2, 4-13, 2012.

Neubauer, W., Doneus, M., Trinks, I., Verhoven, G., Hinterleitner, A., Seren, S., and Löcker, K.: Long-term integrated archaeological prospection at the Roman town of Carnuntum/Austria - Archaeological Survey and the City. Oxbow Books, Oxford, UK, 202-221, 2013.

Oldroyd, D., Amador, F., Kozak, J., Carneiro, A., and Pinto, M.: The study of earthquakes in the hundred years following the Lisbon earthquake of 1755, Earth Sciences History, History of the Earth Sciences Society, 26, 321-370, 2007.

ÖNORM: Belastungsannahmen im Bauwesen, Erdbebenkräfte an nicht schwingungsanfälligen Bauwerken - ÖNORM B 4015, Austrian Standards Institute (ON), DK 624.042.7:550.34 (436), 10 pp., 1979.

ÖNORM: Belastungsannahmen im Bauwesen, Außergewöhnliche Einwirkungen, Erdbebeneinwirkungen, Grundlagen - ÖNORM B 4015-1, Austrian Standards Institute (ON), ICS 91.010.30, 1997.

Pesaresi, D., Picozzi, M., Živčić, M., Lenhardt, W., Mucciarelli, M., Elia, L., Zollo, A., and Gosar, A.: A cross-border regional earthquake early warning system: PRESTo@CE3RN, Nat. Hazards, 86, 431-440, https://doi.org/10.1007/s11069-016-2695-0, 2017.

Picozzi, M., Elia, L., Pesaresi, D., Zollo, A., Mucciarelli, M., Gosar, A., Lenhardt, W., and Zivcic, M.: Trans-National Earthquake Early Warning (EEW) in North-Eastern Italy, Slovenia and Austria: First Experience with PRESTo at the $\mathrm{CE}^{3} \mathrm{RN}$ Network, EGU2014 SM1.2/GI3.7 session, 19 pp., 2014.

Sakal, F., Müller, D., Hinterleitner, A., Löcker, K., and Seren, S.: Jebel el-Hamam, Final report about the Syrian-German Survey, Zeitschrift für Orient-Archäologie, Band 7, ISBN 978-3-80300221-1, 158-196, 2014.

Seren, S., Blaumoser, N., and Melichar, P.: Erfassung von Altlasten, in: Hammerl et al., 2001, 717-725, 2001a.

Seren, S., Eder-Hinterleitner, A., and Melichar, P.: 3D-Erkundung mittels Georadar und Seismik im Felshohlraumbau, in: Hammerl et al., 2001, 707-716, 2001b.

Seren, S., Löcker, K., Hinterleitner, A., and Ladstätter, S.: Ephesos revisited: A decade of geophysical prospection on different field conditions in Ephesos, Turkey, 9. International Conference on Archaeological Prospection in Izmir/Türkei, Proceedings, 9092, 2011. 
Sevara, C., Salisbury, R., Totschnig, R., Doneus, M., Löcker, K., and Tusa, S.: New discoveries at Mokarta, a Bronze Age hilltop settlement in western Sicily, Antiquity, 94, 686-704, https://doi.org/10.15184/aqy.2019.171, 2020.

Suess, E.: Die Erdbeben Nieder-Österreichs, Denkschrift Kgl. Akad. Wissenschaft, Wien, Mat. Naturw., Klasse 33, 61-98, 1873.

Toperczer, M.: Das geophysikalische Observatorium WienKobenzl. Arch. f. Met., Geoph. und Bioklimatologie, Serie: Meteorologie und Geophysik, Band 9, 3. Heft, 1956.

Toperczer, M.: Die Geschichte der Geophysik an der Zentralanstalt für Meteorologie und Geodynamik, Arb. aus der Zentralanst. f. Met. und Geodyn., Publ. Nr. 208, 24 pp., 1975.

Toperczer, M. and Trapp, E.: Ein Beitrag zur Erdbebengeographie Österreichs nebst Erdbebenkatalog 1904-1948 und Chronik der Starkbeben. Mitteilungen der Erdbeben-Kommission, Neue Folge Nr. 65, Österr. Akad. d. Wissenschaften, Vienna, Austria, 59 pp., 1950.
TSN: Total Slovenia News, available at: https://www.total-slovenia-news.com/lifestyle/

1046-old-photos-ljubljana-after-the-earthquake, last access: 17 February 2020.

Vicentini, G. and Pacher, G.: Considerazioni sugli apparecchi sismici registratori e modificazione del microsismografo a due componenti, Boll. Soc. sism. ital. II, 107-121, 1896.

Vicentini, G. and Pacher, G.: Microsismografo per la componente verticale, Atti Ist. veneto Sci. Ser., 7, 65-89, 1898.

Wiechert, E.: Ein astatisches Pendel hoher Empfindlichkeit zur mechanischen Registrierung von Erdbeben, Gerlands Beiträge zur Geophysik, Bd. VI, 435-450, 1904.

ZAMG: "Jahrbuch 1856", Annual report of ZAMG, Library of the ZAMG, Vienna, 1856.

ZAMG: Photo by Lammerhuber on behalf of ZAMG, Archive of ZAMG, 2014.

ZAMG: $\quad$ Stonehenge, https://www.

zamg.ac.at/cms/de/geophysik/news/

neue-entdeckung-bei-stonehenge-mit-oesterreichischer-beteiligung, last access: 1 December 2020. 